\title{
PHYTOCHEMICAL EXTRACTIONS, QUALITATIVE ANALYSIS, AND EVALUATION OF ANTIMICROBIAL ACTIVITY IN THE LEAF AND STEM BARK OF SOLANUM PUBESCENS WILLD.
}

\author{
SUDHAMA VN ${ }^{1,2}$, RAMAKRISHNAN $\mathbf{M}^{1,3 *}$ \\ ${ }^{1}$ Research and Development Centre, Bharathiar University, Coimbatore, Tamil Nadu, India. ${ }^{2}$ Department of Botany, Indavara Dodda \\ Siddalinge Gowda Government College, Chikkamagaluru, Karnataka, India. ${ }^{3}$ Department of Environmental Studies, School of Engineering, \\ Presidency University, Bengaluru, Karnataka, India. Email: maniramiyer@yahoo.com
}

Received: 24 October 2018, Revised and Accepted: 30 November 2018

ABSTRACT

Objective: The objective of this study was to extract the phytochemicals from leaf and stem bark of Solanum pubescens, perform qualitative analysis, and evaluate antimicrobial activity of the phytochemicals against certain microbial pathogens.

Methods: Leaf and stem bark of $S$. pubescens was subjected to phytochemical extractions using Soxhlet apparatus with five different solvents, identified the major constituents in different solvent extracts using standard protocols and investigated the potential antimicrobial activities of the extracts against certain selected bacterial and fungal pathogens by agar well diffusion method.

Results: The maximum yield was in methanolic extracts of leaf and stem bark of the study plant such as 18.51 and $12.5 \%$, respectively, followed by the hydroalcohol extracts (14.23 and 10.00\%). Qualitative phytochemical analysis revealed maximum number of extracted bioactive compounds when compared to other similar studies. Among the five different solvent extracts of $S$. pubescens, n-hexane extract of stem bark was found to be active against all the bacterial pathogens and stem bark extracts made with methanol and hydroalcohol showed antifungal activity against all the four fungal pathogens tested. Leaf extracts made with solvents such as n-hexane and ethyl acetate showed inhibition against Klebsiella pneumoniae and Staphylococcus aureus, respectively, hydroalcohol extract was active against Pseudomonas aeruginosa and Salmonella typhimurium while none of the leaf extracts of the study plant showed inhibition zones against fungal pathogens tested.

Conclusion: Multiple solvent extraction approach yielded the phytochemicals which are not yet reported and the antimicrobial activities of phytochemicals acknowledged their medicinal value.

Keywords: Solanum pubescens, Chitradurga district, Phytochemicals, Antimicrobial.

(C) 2019 The Authors. Published by Innovare Academic Sciences Pvt Ltd. This is an open access article under the CC BY license (http://creativecommons. org/licenses/by/4. 0/) DOI: http://dx.doi.org/10.22159/ajpcr.2019.v12i3.30389

\section{INTRODUCTION}

Plants are potent source of enormous varieties of the secondary plant metabolites biosynthesized by them. The beneficial physiological and therapeutic effects of plant materials typically result from the combinations of these secondary products present in the plants. Solanum pubescens Willd. is an important medicinal plant used in the treatment of several diseases by tribal people in India. It is an annual erect wild shrub found in the forest and hilly areas of Chitradurga district of Karnataka state, India. The plant is bitter in taste due to the presence of alkaloids and the compound like myricetin methyl ethers was reported from the leaves of $S$. pubescens [1]. It is commonly used for treating whooping cough by the local traditional practitioners [2], potentially used in pharmacological studies such as antidiabetic [3], anti-inflammatory activity [4], antidiarrheal activity [5], and antinociceptive screening [6]. Phytochemical screening of the dried fruit materials of $S$. pubescens revealed the presence of carbohydrates, saponins, oils and fats, alkaloids, and flavonoids [7], it is used to treat different diseases such as headache, menstrual pain, rheumatoid arthritis, tuberculosis, ulcers [6], anticonvulsant and sedative effects [8], antibacterial activity, treatment of epilepsy, and febrile convulsions [9]. Methanolic leaf extracts of this plant were also investigated and the presence of alkaloid, glycoside, saponins, phenolic compounds, tannins, and flavonoids was reported [10]. Phytochemical profiling studies on fruit and stem bark of S. pubescens yielded the presence of oils and fats, alkaloids, flavonoids, carbohydrates, saponins, coumarins, and phenolics [11]. Plant-based drugs are effective in the treatment of communicable diseases and reduce many of the side effects that arise due to the use of synthetic antimicrobials [12]. Plants are new source for screening potential antifungal and antibacterial agents and the therapeutic potency of plant-based drugs playing a greater role in health care [13]. Natural products of higher plants may possess a new source of antimicrobial agents with possibly novel mechanisms of action [14]. At the same time, infections have increased to a great extent and antibiotic resistance effects become an ever-increasing therapeutic problem [15]. Research works on the activity of plant extracts against the bacterial and fungal pathogens have been carried out in different parts of the world $[16,17]$. However, in the leaf, fruit, and stem bark of $S$. pubescens, only solvents such as methanol, ethyl acetate, ethanol, chloroform, and hexane were used to extract the phytochemicals, to identity and to investigate the antimicrobial activity. The solvent-like hydroalcohol ( $70 \%$ of water in alcohol) in comparison with different organic solvents has not been attempted for the extraction of bioactive compounds from $S$. pubescens. Therefore, in the present investigation, a comprehensive qualitative phytochemical extraction using five different solvents from the leaves and stem barks of $S$. pubescens was made to evaluate the ability of phytochemicals against six bacterial and four fungal pathogens that cause disease in plants and humans. It helps us to reveal the major bioactive principle compounds, their type and antimicrobial effect.

\section{METHODS}

Plant material collection and identification

The study plant, $S$. pubescens was collected from the hilly areas of Chitradurga district, Karnataka state, India, located at 13.95 N 76.62 E. The plant was confirmed by referring phytographia [18] and further authenticated by Prof. L. Rajanna, Chairperson, Department of Botany, 
Bangalore University, Bengaluru, Karnataka, India. The plant herbarium is deposited and maintained in the Department of Botany, Indavara Dodda Siddalinge Gowda Government College, Chikkamagaluru, Karnataka, India.

\section{Growth and maintenance of bacterial and fungal cultures}

Bacteria (Klebsiella pneumoniae, Vibrio cholerae, Streptococcus pneumoniae, Staphylococcus aureus, Pseudomonas aeruginosa, and Salmonella typhimurium) and fungal cultures (Alternaria alternata, Aspergillus niger, Aspergillus flavus, and Colletotrichum gloeosporioides) were obtained from the Department of Botany, Bangalore University, Jnanabharathi Campus, Bengaluru, Karnataka, India. The bacterial species were maintained on nutrient agar (NA) plates at $37^{\circ} \mathrm{C}$ and fungal species on potato dextrose agar (PDA) at room temperature.

\section{Sample preparation and Soxhlet extraction}

The healthy plant leaves and stems were collected, thoroughly washed in distilled water and blotted. The leaves and stem barks were shade dried for 3 weeks, the dried leaves and stem barks were individually pulverized in a mixer, sieved with a fine mesh, and subjected for consecutive extraction in a Soxhlet extractor using different solvents such as n-hexane, chloroform, ethyl acetate, methanol, and hydroalcohol. All the extracts were concentrated to dry under reduced pressure to yield dried extracts and stored at $4^{\circ} \mathrm{C}$ till further use. The solvents and all other chemicals used for the present study are analytical grade and were purchased from Merck and HiMedia, India.

Qualitative phytochemical analysis

Phytochemicals from leaves and stem barks were extracted using five different solvents and qualitative phytochemical analyses were made using standard protocols. The different tests such as Molisch's test for carbohydrates [19], test for betacyanins [20], test for quinones [21], Mayer's test for alkaloids [22], ninhydrin test for amino acids [23], Biuret test for proteins [24], Benedict's test for reducing sugars [19,25], stain test for fixed oils and fats, ferric chloride test for flavonoids [26], test for gums and mucilages [27], test for tannins [28], acetone $\mathrm{H}_{2} \mathrm{O}$ test for resins, test for phlobatannins [20], Salkowski's test for terpenoids [22], ferric chloride test for phenols [29], foam test for saponins [30], Keller-Killani's test for cardiac glycosides [31], Borntrager's test for anthraquinones [19,32], test for volatile oils, and test for emodols [28] were performed.

\section{Antibacterial and antifungal assay of extracts by agar well diffusion method}

About $20 \mathrm{ml}$ of the sterilized NA was poured uniformly into sterile glass Petri plates, allowed to solidify and then, $0.5 \mathrm{ml}$ of suspension of the test organisms ( $K$. pneumoniae, V. cholerae, $S$. pneumoniae, $S$. aureus, $P$. aeruginosa, and $S$. typhimurium) was spread evenly on the medium with sterilized L-shaped glass rod to get a uniform inoculation of bacteria. Then, the wells were prepared with the help of clean and sterilized cork borer of $6 \mathrm{~mm}$ diameter at three corners of the plate and different solvent extracts of the leaf and stem bark of S. pubescens were dissolved in $10 \%$ dimethyl sulfoxide (DMSO) and loaded to the wells with $100 \mu \mathrm{l}$ micropipette $(50,100$, and $150 \mathrm{mg} / \mathrm{ml})$. Standard drug tetracycline, a positive control $(1 \mathrm{mg} / \mathrm{ml}$ concentration) and $10 \%$ DMSO and negative control were loaded separately into respective labeled wells and incubated at $37^{\circ} \mathrm{C}$ for $24 \mathrm{~h}$ in an upright position. The antibacterial activity was evaluated by measuring the diameter $(\mathrm{mm})$ of inhibition zones formed around the well, compared with the control and recorded.

Table 1: Nature of the extract and yield of leaf and stem bark extracts of S. pubescens

\begin{tabular}{lllllll}
\hline S. No & Name of the solvent & Plant material (g) & Nature of the extract & & Yield (\%)* \\
\cline { 3 - 5 } & & Leaf extract & Bark extract & Leaf extract & Bark extract \\
\hline 1 & n-hexane & 120 & Brown sticky mass & Brownish sticky mass & 3.92 & 2.08 \\
2 & Chloroform & 120 & Brownish-black sticky & Dark green sticky powder & 9.84 & 4.37 \\
3 & Ethyl acetate & 120 & Dark greenish shiny sticky & Greenish powder & 7.26 & 2.50 \\
4 & Methanol & 120 & Dark greenish sticky & Light green with shiny powder & 18.51 & 12.50 \\
5 & Hydroalcohol & 120 & Brown sticky solid & Orange-brown & 14.23 & 10.00 \\
\hline
\end{tabular}

*Values are observations from triplicate readings and expressed as mean \pm standard deviation, S. pubescens: Solanum pubescens

Table 2: Qualitative phytochemical analysis data in the leaf and stem bark extracts of $S$. pubescens

\begin{tabular}{|c|c|c|c|c|c|c|c|c|c|c|c|}
\hline \multirow[t]{2}{*}{ S. No } & \multirow[t]{2}{*}{ Phytochemicals } & \multicolumn{2}{|l|}{$\mathbf{H x}$} & \multicolumn{2}{|c|}{ Chl } & \multicolumn{2}{|c|}{ Et Ac } & \multicolumn{2}{|c|}{ Mtl } & \multicolumn{2}{|c|}{ Hyal } \\
\hline & & LE & BE & LE & BE & LE & $\mathrm{BE}$ & LE & $\mathrm{BE}$ & LE & BE \\
\hline 1 & Carbohydrates & - & + & + & + & + & + & + & + & - & + \\
\hline 2 & Betacyanins & + & + & - & + & + & + & - & + & + & + \\
\hline 3 & Quinones & - & + & - & + & - & + & - & - & + & + \\
\hline 4 & Alkaloids & + & - & + & + & - & - & + & + & + & + \\
\hline 5 & Amino acids & - & - & - & - & - & - & - & + & - & + \\
\hline 6 & Proteins & + & + & + & + & + & + & + & - & - & + \\
\hline 7 & Reducing sugars & - & - & - & - & - & - & - & - & - & - \\
\hline 8 & Fixed oils and fats & + & + & + & - & + & - & + & - & + & - \\
\hline 9 & Flavonoids & - & - & + & - & + & - & + & + & - & + \\
\hline 10 & Gums and mucilages & - & - & - & - & - & - & - & - & - & - \\
\hline 11 & Tannins & + & + & + & + & + & - & + & + & + & + \\
\hline 12 & Resins & - & - & + & + & + & + & - & - & - & - \\
\hline 13 & Phlobatannins & - & - & - & - & - & - & - & - & - & - \\
\hline 14 & Terpenoids & - & - & - & + & - & - & + & - & - & - \\
\hline 15 & Phenols & + & - & + & + & + & - & + & - & - & - \\
\hline 17 & Cardiac glycosides & - & - & - & - & - & - & - & - & - & - \\
\hline 18 & Anthraquinones & - & - & + & - & - & - & - & - & - & - \\
\hline 19 & Volatile oils & - & + & - & - & - & - & + & + & - & + \\
\hline 20 & Emodols & - & - & - & - & - & - & - & - & - & + \\
\hline
\end{tabular}

LE: Leaf extract, BE: Stem bark extract, Hx: n-hexane, Chl: Chloroform, Et Ac: Ethyl acetate, Mtl: Methanol, Hyal: Hydroalcohol. + indicates present, - indicates absent.

*Values are observations from triplicate readings, S. pubescens: Solanum pubescens 
To investigate the antifungal properties of the extracts, the sterilized and autoclaved PDA media was brought to $40^{\circ} \mathrm{C}$, added $0.5 \mathrm{ml}$ of the standard spore suspension, $20 \mathrm{ml}$ of PDA media was poured onto the Petri plate, mixed gently by avoiding air bubbles formation, and allowed for complete solidification. Wells ( $6 \mathrm{~mm}$ diameter) were bored onto the solidified agar media using sterile cork borer, wells were loaded with $50 \mu \mathrm{l}$ of crude extract $(50,75$, and $100 \mathrm{mg} / \mathrm{ml})$, and the plates were kept for $1 \mathrm{~h}$ to allow the diffusion of solution into the medium. The standard drug fluconazole (1 mg/ml), a positive control and 10\% DMSO and a negative control were loaded separately into respective labeled wells and the plates were incubated at room temperature overnight. Zone of inhibitions was measured at 24 and $48 \mathrm{~h}$ intervals from the edge of the wells, recorded, and compared with standard [33]. All the experiments were conducted in three replicates, the mean value and reproducible data were considered.

\section{RESULTS}

\section{Nature and yield of the extracts}

The percentage yield of extracts from leaf and stem bark of the study plant was calculated (Table 1). Among the leaf extracts, the methanolic extract has maximum yield of $18.51 \%$ followed by hydroalcohol (14.23\%), chloroform (9.84\%), ethyl acetate $(7.26 \%)$, and $n$-hexane (3.92\%). For the stem bark, methanolic extract has maximum yield of $12.5 \%$ followed by hydroalcohol (10.00\%), chloroform (4.37\%), ethyl acetate $(2.5 \%)$, and $\mathrm{n}$-hexane $(2.08 \%)$.

\section{Phytochemical analysis}

The qualitative phytochemical analysis in the leaves and stem bark extracts of $S$. pubescens revealed the presence and absence of compounds (Table 2).

The present investigation yielded the presence of carbohydrates, betacyanins, quinones, alkaloids, amino acids, proteins, fixed oils and fats, flavonoids, tannins, resins, terpenoids, phenols, saponins, anthraquinones, volatile oils, and emodols while reducing sugars, gum mucilages, phlobatannins, and cardiac glycosides were absent. Quinones were found in the bark extracts of all five different solvents. Amino acids were present only in the methanol and hydroalcohol extracts of stem bark, at the same time, anthraquinones were present in the chloroform extract from leaf and emodols found extracted only in the stem bark of the study plant with hydroalcohol solvent. The leaf extract of Solanum nigrum shows negative results for terpenoids and saponins [34]. Similarly, Solanum torvum showed the presence of terpenoids, alkaloids, saponins, and sterols [35].

\section{Antibacterial and antifungal assay}

Antibacterial activity of leaf and stem bark extracts of S. pubescens was examined against K. pneumoniae, V. cholerae, S. pneumoniae, S. aureus, $P$. aeruginosa, and S. typhimurium and the extracts exhibited inhibition activity against one or more test organisms (Table 3 ).

Among the five different solvent extracts of $S$. pubescens, $\mathrm{n}$-hexane extract of stem bark was found to be active against all the bacterial pathogens, the leaf extracts made with solvents such as n-hexane and ethyl acetate showed inhibition against $K$. pneumoniae and S. aureus, respectively, while hydroalcohol extracts showed inhibition against $P$. aeruginosa as well as $S$. typhimurium. The n-hexane extract from stem bark of the study plant found to be active significantly $(8.66 \pm 0.57,14.33 \pm 0.57$, and $15.33 \pm 0.57 \mathrm{~mm}$ at 50,100 , and $150 \mathrm{mg} / \mathrm{ml}$ concentration, respectively) against $K$. pneumoniae while the lowest zone of inhibition observed in the ethyl acetate extract of leaf of the study plant against $P$. aeruginosa $(1.33 \pm 0.57,2.66 \pm 0.57$, and $4.33 \pm 0.57 \mathrm{~mm}$ at 50,100 , and $150 \mathrm{mg} /$ $\mathrm{ml}$ concentration, respectively). DMSO a negative control showed no inhibition zones. Chloroform extracts from the leaf and stem bark did not show zone of inhibition for any of the bacterial pathogens used in the study. The standard drug tetracycline, a positive control showed maximum zone of inhibition $7.33 \pm 0.57 \mathrm{~mm}$ against $P$. aeruginosa for the stem bark extract followed by $6.33 \pm 0.57 \mathrm{~mm}$ against $P$. aeruginosa for the leaf extract and $5.66 \pm 0.57 \mathrm{~mm}$ against $V$. cholerae for the stem 人ñ

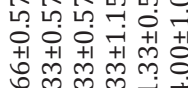

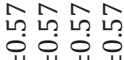

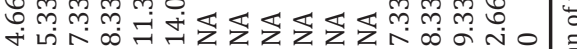

เกิ ำㅇํㅇ

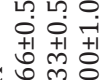

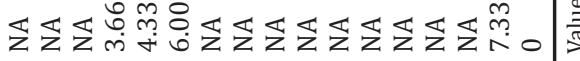

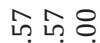

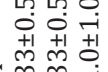

กิ

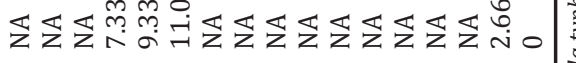

ถิำใำำ

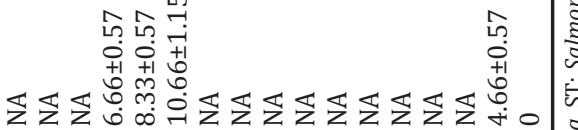

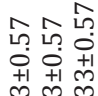

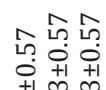

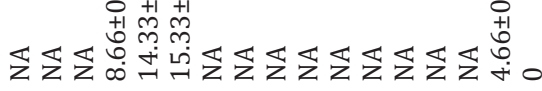

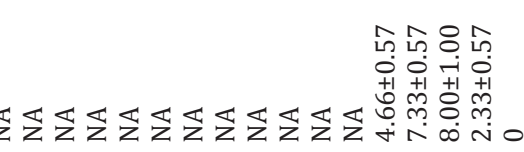

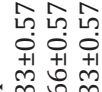
列 
Table 4: Inhibition zone of different solvent extracts from leaf and stem bark parts of $S$. pubescens against four different fungi

\begin{tabular}{|c|c|c|c|c|c|c|c|c|c|}
\hline \multirow[t]{3}{*}{ Solvents } & \multirow[t]{3}{*}{ Conc. $\mathrm{mg} / \mathrm{ml}$} & \multicolumn{8}{|c|}{ Name of the fungal pathogens and inhibition zone (mm) } \\
\hline & & AA & AN & AF & CG & AA & AN & AF & CG \\
\hline & & \multicolumn{4}{|c|}{ Leaf extract } & \multicolumn{4}{|c|}{ Bark extract } \\
\hline \multirow[t]{3}{*}{ Methanol } & 50 & NA & NA & NA & NA & $2.33 \pm 0.57$ & $1.33 \pm 0.57$ & $3.66 \pm 0.57$ & $6.33 \pm 0.57$ \\
\hline & 75 & NA & NA & NA & NA & $2.66 \pm 0.57$ & $2.33 \pm 0.57$ & $4.66 \pm 0.57$ & $7.33 \pm 0.57$ \\
\hline & 100 & NA & NA & NA & NA & $4.66 \pm 0.57$ & $3.66 \pm 0.57$ & $5.66 \pm 0.57$ & $8.66 \pm 0.57$ \\
\hline \multirow[t]{2}{*}{ n-hexane } & 50 & NA & NA & NA & NA & NA & NA & NA & NA \\
\hline & 100 & NA & NA & NA & NA & NA & NA & NA & NA \\
\hline \multirow[t]{3}{*}{ Ethyl acetate } & 50 & NA & NA & NA & NA & NA & NA & NA & NA \\
\hline & 75 & NA & NA & NA & NA & NA & NA & NA & NA \\
\hline & 100 & NA & NA & NA & NA & NA & NA & NA & NA \\
\hline \multirow[t]{3}{*}{ Chloroform } & 50 & NA & NA & NA & NA & NA & NA & NA & NA \\
\hline & 75 & NA & NA & NA & NA & NA & NA & NA & NA \\
\hline & 100 & NA & NA & NA & NA & NA & NA & NA & NA \\
\hline \multirow[t]{2}{*}{ Hydroalcohol } & 50 & NA & NA & NA & NA & $11.33 \pm 0.57$ & $11.33 \pm 0.57$ & $2.33 \pm 0.57$ & $4.66 \pm 0.57$ \\
\hline & 100 & NA & NA & NA & NA & $15.00 \pm 1.00$ & $25.33 \pm 2.30$ & $4.66 \pm 0.57$ & $7.33 \pm 0.57$ \\
\hline Standard drug fluconazole & 10 & $5.00 \pm 1.00$ & $4.66 \pm 0.57$ & $3.66 \pm 1.15$ & $3.33 \pm 0.57$ & $7.00 \pm 1.00$ & $6.33 \pm 1.52$ & $4.66 \pm 0.57$ & $7.33 \pm 0.57$ \\
\hline Control 10\% DMSO & - & 0 & 0 & 0 & 0 & 0 & 0 & 0 & 0 \\
\hline
\end{tabular}

AA: Alternaria alternata, AN: Aspergillus niger, AF: Aspergillus flavus, CG: Colletotrichum gloeosporioides. Values are mean of three independent experiments, \pm standard deviation. NA: Not active, DMSO: Dimethyl sulfoxide

bark extract. Similar zone of inhibitions values $(4.66 \pm 0.57 \mathrm{~mm})$ was observed, recorded for the leaf extract and stem bark extracts against $V$. cholerae, K. pneumoniae, as well as S. pneumoniae. While, the lowest zone of inhibition $2.33 \pm 0.57 \mathrm{~mm}$ was recorded against Salmonella typhimurium in the leaf extract.

The antifungal activity of the leaf and stem bark extracts of different solvents was made by the agar well diffusion method against four pathogenic fungal species (A. alternata, A. niger, A. flavus, and $C$. gloeosporioides) and recorded the zone of inhibition for each fungal strain at different concentrations, namely 50, 75, and $100 \mathrm{mg} / \mathrm{ml}$ (Table 4).

Antifungal activity of the stem bark extracts of $S$. pubescens made with methanol and hydroalcohol showed zone of inhibition against all the four fungal pathogens (A. alternate, A. niger, A. flavus, and C. gloeosporioides) while none of the leaf extracts made with five different solvents show inhibition zones. The standard drug fluconazole $(10 \mathrm{mg} / \mathrm{ml}$ concentration) was used as positive control at 50,75 , and $100 \mathrm{mg} / \mathrm{ml}$ concentration and it recorded $5.00 \pm 1.00,4.66 \pm 0.57$, $3.66 \pm 1.15$, and $3.33 \pm 0.57 \mathrm{~mm}$ zone of inhibition against A. alternata, A. niger, A. flavus, and C. gloeosporioides, respectively. DMSO, a negative control used at $10 \%$ concentration, did not show any zone of inhibition.

\section{DISCUSSION}

Phytochemical extractions studies by Rahman et al. [11] on S. pubescens in the stem bark using hexane, chloroform, ethyl acetate, and ethanol yielded $1.24 \%, 1.08 \%, 3.55 \%$, and $11.59 \%$, respectively. While in the present study, the use of solvents for extraction with methanol and hydroalcohol has significantly enhanced the recovery percentage from both leaf and stem bark (Table 1 ). This suggests that the use of methanol and hydroalcohol yielded more number of bioactive compounds from the study plant when compared to the yield of other solvents. Investigations on antibacterial activity of chloroform extract from stem bark of S. pubescens at $80-160 \mu \mathrm{g} / \mathrm{ml}$ concentrations against Bacillus subtilis and E. coli with potential inhibition of 81.44 and $82.17 \%$ were reported [9]. Similarly, Gandhiappan and Rangaswamy [36] reported the antibacterial activity studies against $K$. pneumoniae, $V$. cholerae, $M$. luteus, and $S$. aureus with the phytochemicals extracted using chloroform, ethyl acetate, and methanol from leaf of $S$. pubescens at $250 \mu \mathrm{g}, 500 \mu \mathrm{g}, 750 \mu \mathrm{g}$, and $1000 \mu \mathrm{g} / \mathrm{ml}$ concentrations. Interestingly, a report on antifungal activity of phytochemical extracts using ethyl acetate from leaf of $S$. pubescens was found effective against C. parapsilosis and $C$. tropicalis but not active against $C$. albicans. In the present investigation, it is observed that the zone of inhibition trend of antibacterial $(8.66 \pm 0.57,14.33 \pm 0.5$, and $15.33 \pm 0.57 \mathrm{~mm}$ at 50,100 , and $150 \mathrm{mg} / \mathrm{ml}$ concentration, respectively) activity and antifungal activity $(11.33 \pm 0.57,13.33 \pm 1.15$, and $15.00 \pm 1.00 \mathrm{~mm}$ at 50,75 , and $100 \mathrm{mg} / \mathrm{ml}$ concentration, respectively) increased proportionately with the increase in the concentration of phytochemical extracts made using five different solvents from both leaf and stem bark of S. pubescens.

\section{CONCLUSION}

The present study with the focus on the use of different solvents for phytochemical extraction found that methanol and hydroalcohol would be the suitable solvents for extraction of potential antimicrobial bioactive compounds from the leaf and stem bark of $S$. pubescens, phytochemical screening and antimicrobial activity of the leaf and stem bark extracts of the study plant showed the presence of potential bioactive compounds and can act as good antimicrobial agents. Our study proved that the increase in the concentration of plant extracts increases the antimicrobial activity, the methanol and hydroalcohol extracts showed significant control against all the test organisms and the hydroalcohol extract is more efficient than the standard drug tested. A systematic phytochemical screening in the extracts made using different solvents revealed more phytoconstituents from S. pubescens, the antimicrobial study further infers that the stem bark of $S$. pubescens is effective plant drug source against bacterial and fungal pathogens and it is presumed that the presence of antimicrobial agents in stem bark could have attributed to a valuable medicinal source of the study plant. Further studies on isolation, identification, and characterization of bioactive compounds in this plant are in progress.

\section{AUTHORS' CONTRIBUTIONS}

First author has plan the research work, design the experiments, carried out all the experiments, data compilations, statistical analysis, and preparation of the manuscript under the guidance of the second author. The second author has made critical observations in the manuscript and developed the final publishable format.

\section{CONFLICTS OF INTEREST}

The authors declare no conflicts of interest. 


\section{REFERENCES}

1 Kumari GN, Rao LJ, Rao NS. Flavonol 3-0-methyl ethers from Solanum pubescens. J Nat Prod 1985;48:149-50.

2 Reddy KN, Reddy CS, Trimurthulu G. Ethnobotanical survey on respiratory disorders in Eastern Ghats of Andhra Pradesh, India. J Ethnopharmacol 2006;10:139-48.

3 Hemamalini K, Krishna VR, Bhargav A, Reddy UV. Hepato protective activity of Tabebuia rosea and Solanum pubescens against paracetamol induced hepatotoxicity in rats. Asian J Pharm Clin Res 2012;5:4.

4 Niyogi P, Raju NJ, Reddy PG, Rao BG. Formulation and evaluation of anti-inflammatory activity of Solanum pubescens Wild extracts gel on albino wister rats. Int J Pharm 2012;2:484-90.

5 Hemamalini K, Bhargav A. Antidiarrheal activity of methanolic extracts of leaves of Solanum pubescens Willd. Int J Pharmacol Toxicol 2013;3:43-5.

6 Sumalataha P, Hemamalini K, Shwetha R, Reddy UV. Antinociceptive screening of methanol extract of Solanum pubescens. Phytomedicine 2013;4:149-51.

7 Rahman H, Mahmood R, Nazeen MH. Phytochemical analysis of Solanum pubescens. Kuvempu Univ Sci J 2012;5:71-9.

8 Kiranmai AS, Hemamalini K, Reddy UV. Anticonvulsant and sedative effects of leaf extract of Solanum pubescens. Int J Pharm Sci Res 2013;4:1424-7.

9 Rahman H, Mahmood R, Rahman N, Haris M. Antibacterial activity of Solanum pubescens an ethnomedicinal plant from south western region of Andhra Pradesh. Int J Appl Sci Biotechnol 2014;2:501-9.

10 Ayyadurai V, Ramar K. Preliminary phytochemical analysis of methanolic leaves extract of Solanum pubescens Willd. Imp J Interdiscip Res 2017;3:1746-9.

11 Rahman H, Mahmood R, Haris M, Rahman N. Phytochemical profiling of successive extracts of fruit and stem bark of Solanum pubescens. Int J Pharm Pharm Sci 2014;6:147-53.

12 Iwu MM, Duncan AR, Okunji CO. New Antimicrobials of plant origin. In: Janick J, editor. Perspectives on New Crops and New Uses. Alexandria: ASHS Press; 1999. p. 457-62.

13 Motsei ML, Lindsey KL, Van Staden J, Jaeger AK. Screening of traditionally used South African plants for anti-fungal activity against Candida albicans. J Ethnopharmacol 2003;86:235-41.

14 Barbour EK, Al Sharif M, Sagherian VK, Habre AN, Talhouk RS, Talhouk SN. Screening of selected indigenous plants of Lebanon for antimicrobial activity. J Ethnopharmacol 2004;93:1-7.

15 Mahesh B, Satish S. Antimicrobial activity of some important medicinal plant against plant and human pathogens. World J Agric Sci 2008;4:839-43.

16 Shashikant VB, Deshmane BJ, Dangare SC, Suraj T. Anticovulsant activities of some novel 3-[5-substituted 1, 3, 4-thiadiazole-yl]-2-styryl quinazoline-4(3h)-ones. Pharmacol Online 2008;2:604-13.
17 Naidoo VV. An antimicrobial investigation of plants used traditionally in southern Africa to treat sexually transmitted infections. J Ethnopharmacol 2010;130:552-8.

18 Phytographia: 5. t. 3. (1794) FBI 4: 230, Gamble, 2, 936, (1883).

19 Sofowara A. Medicinal Plants and Traditional Medicine in Africa. $2^{\text {nd }}$ ed. Ibadan, Nigeria: Spectrum Books, Ltd.; 1993. p. 150-6.

20 Harborne JB. Phytochemical Methods, A Guide to Modern Techniques of Plant Analysis. $2^{\text {nd }}$ ed. London, New York: Chapman and Hall, Ltd.; 1973. p. 49-188.

21 Evans WC. Pharmacognosy. $14^{\text {th }}$ ed., Vol. 9. Singapore: W. B. Saunders Co. Ltd.; 1996. p. 713-34.

22 Evans WC. Pharmacology. Asia, Singapore: Harcourt Brace and Company; 1997. p. 226-8.

23 Yasuma A, Ichikawa T, A new histo chemical staining method for protein. J Lab Clin Med 1953;41:296-9.

24 Brain KR, TurnerTD. The Practical Evaluation of Phytopharmaceuticals. $2^{\text {nd }}$ ed. Bristol: Wright Scientechnica; 1975. p. 81-2.

25 Kumar BT, Kaur M, Kaur G, Kaur H. Phytochemical screening and extraction: A review. Int Pharm Sci 2011;1:98-106.

26 Raman N, Phytochemical Techniques. New Delhi: New Indian Publishing Agency; 2006. p. 19.

27 Whistler RL, Bemiller JN. Industrial Gums: Polysaccharides and Their Derivatives. San Diego: Academic press; 1993. p. 318-37.

28 Trease GE, Evans MD. Trease and Evans Pharmacognosy. 13 $3^{\text {th }}$ ed. London: Bailliere Tindall; 1989. p. 176-80.

29 Gorbach SL, Anaerobic bacteriology for clinical laboratories. Pharmacognosy 1963;23:89-91.

30 Kumar A, Ilavarasan R, Jayachandran T, Decaraman M, Aravindhan P, Padmanaban N, et al. Phyto chemical investigation on a tropical plant, Syzygium cumini from Kuttuppalayam, Erode district, Tamil Nadu, South India. Pak J Nutr 2009;8:83-5.

31 Sofowara A. Medical Plants and Traditional Medicines in Africa. Ibadan, Nigeria: Spectrum Book Ltd.; 1993. p. 191-289.

32 Harborne JB. Phytochemical methods a Guide to Modern Techniques of Plants analysis. Netherlands: Springer; 1998. p. 1-26.

33 Jayadev S, Bird TD. Hereditary ataxias: Over view. Genet Med 2013;15:673-83.

34 Prakash S, Jain AK. Antifungal activity and preliminary phytochemical studies of leaf extract of Solanum nigrumlinn. Int J Pharm Pharm Sci 2011;3:352-5

35 Kalita L, Dash B, Borah U, Deka J, Dash S. Preliminary Phytochemical analysis and antimicrobial activity ethanolic extracts of dried fruits of Solanum torvum (Family-Solanaceae). Int J Curr Pharm Res 2017;9:123-6.

36 Gandhiappan J, Rengasamy R. Comparative evaluation of antimicrobial activities of the members of Solanaceae. Pelagia research library. Der Pharm Sin 2012;3:357-60 